This Section of Epidemiology and Psychiatric Sciences appears in each issue of the Journal and is dedicated to all forms of creative production born of an intimate and individual urge, often secretive, unbound from the conventional art system rules. Through short descriptions of the Outsider art work of prominent artists and new protagonists often hosted in community mental health services, this Section intends to investigate the latest developments of the contemporary art scene, where the distances between the edge and the centre are becoming more and more vague.

Carole Tansella, Section Editor

\title{
Agnes Richter's jacket
}

\section{T. Röske}

Museum Sammlung Prinzhorn, Klinik für Allgemeine Psychiatrie, Universitätsklinik Heidelberg, Heidelberg, Germany

Received 1 April 2014; Accepted 10 April 2014; First published online 13 June 2014

Key words: Artistry of the mentally ill, mental illness, Prinzhorn, textile.
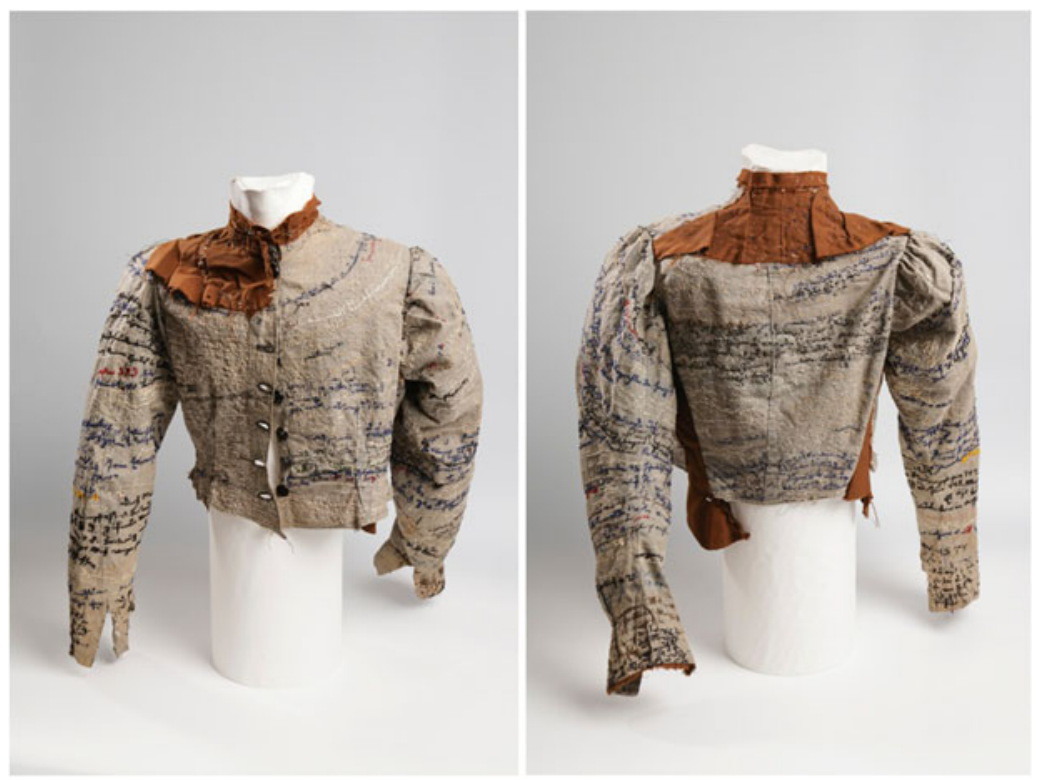

Agnes Richter: Little Jacket, Institutional linen, coloured threads, brown woolen fabric (1895), $38.5 \times 42.0 \mathrm{~cm}$, Prinzhorn Collection, Heidelberg, Inv. Nr. 743. Photograph: Arnaud Conne.

\footnotetext{
Address for correspondence: Dr Thomas Röske, Department of General Adult Psychiatry, Prinzhorn Collection, Centre for Psychosocial Medicine, Vossstrasse. 2, D-69115, Heidelberg, Germany.

(Email: thomas.roeske@med.uni-heidelberg.de)
} 
The little jacket embroidered with text by Agnes Richter dated 1895 (Figures 1 and 2), today one of the icons of the Museum Prinzhorn Collection at Heidelberg, became known only in 1980 through the first big itinerant exhibition of the Prinzhorn Collection in Germany after 1945 (cf. Die PrinzhornSammlung, 1980, p. 284). Hans Prinzhorn, who gathered most of the Heidelberg fund in 1919-21 as an assistant doctor of the psychiatric university clinic, mentions it neither in his pioneering book Bildnerei der Geisteskranken (Artistry of the Mentally Ill) published in 1922 (Prinzhorn, 1922) nor anywhere else. It seems to have been not important for his look at institution art. In the unconventional sartorial work from coarse institution linen and brown wool he probably saw only the craft; and the communication intention which becomes clear in the multi-coloured embroidered text ranks in his expression model of artistic creativity at the last place. Probably he gave to himself no trouble to decipher the written. He looked for medical files and other biographic information anyway only with such institution inmates whose works were of particular interest to him. Usually what psychiatrists from the whole of Germany sent because of his appeal came only with name or initials and diagnosis to Heidelberg.

Therefore, the little jacket was long without the resonating cavity of a biography. At least, a suspended slip of paper betrayed that it belonged to a bigger autobiographic project: 'Seams in all laundry and clothes recollections from her life.' The embroidered oldGerman writing is difficult to decipher, because it is rubbed off at many places or too indistinctly exerted. However, the frequent appearance of 'me' and 'mine' as well as past data confirm the note by a foreign hand. Besides, in the eye falls again and again the figure 583 which is once also noted down in ballpoint pen as if printed. Moreover, the discolorations by sweat at the armpits prove that the textile was worn.

Only in 2003, during the preparation of the Heidelberg exhibition Irre ist weiblich. Künstlerische Interventionen von Frauen in der Psychiatrie um 1900 (Mad is female. Artistic interventions of women in psychiatry about 1900) (cf. Michely, 2004), Richter's medical file of the Hubertusburg asylum was found. First there were even two files, because at the end of the 19th century two Agnes Richters lived in this institution. In none of the files the little jacket is mentioned. Then, however, in one of them a slip of paper was found on which on the top the figure 583 was noted - the laundry number of Richter. Attaching the figure several times, Richter wanted to prevent that the garment got lost with the cleaning.

The information about the biography and appearance of the 1844-born Agnes Richter also speaks of the fact that she sewed it for herself. Before her admission in 1893 she worked as a seamstress, and she was small-grown. Possibly she carried the little jacket up to her death in 1918. The given date 1895 might signify the end of the work on it. Up to now, only a few passages have been deciphered which can be connected with what we know about Richter's life (e.g., 'I am not big', 'my jacket', 'I am in Hubertusburg'). Thus the statement that she carried autobiographic recordings on her body remains more general. In a situation which meant the deprivation of rights and the loss of all possessions, Richter gave, with a usually only decorative, subordinated technology of embroidery, material expression to the most intimate, her own recollection and thus her own psychical hold. More than on the noteworthy self-confidence to dress herself with her own inside, this allows to conclude on want, on the fear to lose herself (cf. Hornstein, 2009).

This is valid in spite of the fact that the text is stitched outside only in the sleeves of the little jacket and inside at the body. This turning around was in fact an afterthought since at the body the seams and darts are mounted outside. Such reversing seems to be in tune with another absurdity of the garment: because of the darts beside the button strips, one supposes first that it was buttoned in front. Then, however, the sleeves would be wrongly attached, because they would bend to the back instead of forward. Did the institution inmate with the wrong, disarranged form of the textiles wish to point to her internment as a 'madwoman'?

The file mentions that the upper part of Richter's body was 'deformed' by a sideways bending of the backbone. Did the darts have, therefore, another function than to form the bust in front - to give place to the 'hunchback'? Was the little jacket buttoned at the back? This use would arouse, especially in the psychiatric context, associations with a straightjacket. However one turns the puzzling facts, it becomes clear that this textile was more to Richter than just a garment. With it she expressed symbolically her situation.

\section{Acknowledgements}

None.

\section{Financial Support}

This research received no specific grant from any funding agency, commercial or not-for-profit sectors.

\section{Conflict of Interest}

None. 


\section{References}

Die Prinzhorn-Sammlung (1980). Bilder, Skulpturen, Texte aus Psychiatrischen Anstalten (ca. 1890-1920). Heidelberger Kunstverein etc. Athenäum: Königstein i.Ts.

Hornstein GA (2009). Agnes's Jacket: A Psychologist's Search for the Meanings of Madness. Rodale: New York.

Michely V (2004). Agnes Richter. In Irre ist weiblich. Künstlerische Interventionen von Frauen in der Psychiatrie um 1900 (ed. Brand-Claussen B and Michely V), p. 146. Exhibition Catalogue Sammlung Prinzhorn etc. Wunderhorn: Heidelberg.

Prinzhorn H (1922). Bildnerei der Geisteskranken. Ein Beitrag zur Psychologie und Psychopathologie der Gestaltung. Springer: Berlin.

\section{About the Author}

Thomas Röske, Ph.D., has been the Director of the Museum Prinzhorn Collection, University Hospital of Heidelberg since 2002. He has been the President of the European Outsider Art Association since 2012 and is a lecturer at the European Institute of Art History, University of Heidelberg.
Dr Röske, as an expert scholar of the artistic events of the 20th century, investigated the less obvious aspects of Outsider art, i.e., introducing the point of view of queer studies.

In the current international art scene, Outsider art has become a well-established protagonist, subjected to increasingly hectic commercial attention. Thomas Röske, interweaving the paradigm of art history with that of psychiatry, is a sensitive guide, capable of raising important questions about the future of a kind of art historically grown at the margins of society.

Among his major publications are: Im Dienste des Ich - Ernst Kris heute, Wien, 2013; Surrealismus und Wahnsinn/Surrealism and Madness, Exhibition catalogue, Sammlung Prinzhorn, Heidelberg, 2009; Künstler in der Irre/Artists off the Rails, Exhibition catalogue, Sammlung Prinzhorn, Heidelberg, 2008; and Der Arzt als Künstler - Ästhetik und Psychotherapie bei Hans Prinzhorn (1886-1933), Bielefeld, 1995.

Carole Tansella, Section Editor 